\title{
اختبار المقالي في تقويم التدريس اللغة العربية لمرحلة الثانوية
}

Dasep Bayu Ahyar ${ }^{1}$, Muhammad Mahpudin ${ }^{2}$

\author{
${ }^{1,2}$ Universitas Islam Negeri Syarif Hidayatullah Jakarta
}

Email: dasepbayuahyar93@gmail.com

DOI: $\underline{10.24252 / \mathrm{saa} . v 8 \mathrm{i} 1.12086}$

$$
\begin{aligned}
& \text { ملخص البحث } \\
& \text { الاختبار هو عملية قياس طالب مراقبة الإنجاز في الانضباط في الفصول الدراسية باستخدام الإختبار. إحدى } \\
& \text { التقييم في التعلم التي يمكن تطبيقها المدرس على الطلاب هو اختبار المقالي. الاختبار (instrument)أدوات } \\
& \text { المقاليّ عبارة عن سؤال أو عدّة أسئلة تعطى للمتعلّمين من أجل الإجابة عنها، وهذه الاختبارات صيغ تكاد تكون } \\
& \text { معروفة في كلّ المواد مثل: اذكر ما تعرفه عن، ناقش المقصود ب، علّل أسباب حدوث، اشرح، وضّح، بيّن، قارن، } \\
& \text { أكتب، ولذلك تحتاج هذه الاختبارات إلى متعلّم حسن التعبير، منطقيّ التفكير، يربط الحوادث ربطاً محكماً، } \\
& \text { ويستخلص منها رأياً، أو يقيم دليلاً، أو يفنّد فرضيّة. سوف تناقش هذه المقالة حول اختبارات المقالي التي تتراوح } \\
& \text { بين التعاريف والمفاهيم والإجراءات حتى إلى استخدامها. } \\
& \text { كلمة المفتاحية: الاختبار المقالي، تقييم، اللغة العربية }
\end{aligned}
$$

\begin{abstract}
Abstrak
Tes merupakan alat untuk mengukur kemampuan (Qudrah) para peserta didik terhadap hasil proses pembelajaran yang mereka tempuh. Alat atau Instrument penilaian dalam proses pembelajaran yang bisa di aplikasikan kepada peserta didik oleh seorang guru salah satunya dengan menggunakan tes uraian. Tes uraian (al Ikhtibār al Maqā í) sendiri menuntut peserta didik untuk menjawab dalam bentuk menguraikan, menjelaskan, mendiskusikan, mebandingkan, memberikan alasan dengan menggunakan kata-kata dan bahasa mereka sendiri. Dalam tulisan ini akan membahas tentang tes uraian (al Ikhtibār al Maqā $\bar{l}$ ) mulai dari definisi, konsep, prosedur, sampai pada penggunaannya.
\end{abstract}

Kata kunci: Tes Uraian, Evaluasi, Bahasa Arab

\section{PENDAHULUAN}

Tujuan utama evaluasi pendidikan (at-Taqwîm at-Tarbawi) dan pembelajaran adalah untuk mengetahui tingkat efektivitas (ketepatan dalam pencapaian tujuan) dan efisiensi (penggunaan tenaga, sarana, biaya dan waktu yang minimal) dalam suatu proses pendidikan secara komprehensif. Selain itu, evaluasi juga bertujuan untuk mengetahui kemajuan belajar peserta didik setelah memperoleh layanan pendidikan dalam jangka waktu tertentu. Karena itu, evaluasi tidak hanya berlaku bagi proses pembelajaran yang berlangsung di dalam kelas, melainkan juga diberlakukan mulai dari perencanaan kurikulum, buku ajar yang digunakan, 
metode dan media pembelajaran, tenaga pendidik dan peserta didik, tingkat keterbacaan (mustawa maqru'iyyah) buku ajar yang digunakan dan sebagainya ${ }^{1}$

Kemahiran dalam menyusun alat evaluasi pembelajaran merupakan salah satu kompetensi yang harus dimiliki oleh seorang guru (al Mudarris), sebab evaluasi merupakan salah satu unsur yang penting dalam proses pembelajaran. Dengan evaluasi, bisa diketahui apakah tujuan pembelajaran bahasa Arab yang telah ditetapkan sudah tercapai atau belum. Selanjutnya, hasil evaluasi itu akan menjadi masukan berupa umpan balik bagi perbaikan atau pengembangan proses pembelajaran berikutnya. $^{2}$

Dalam melakukan evaluasi pembelajaran bahasa Arab diperlukan alat atau instrument. Alat evaluasi pembelajaran ada dua macam, yaitu tes dan non-tes. Alat evaluasi tes biasanya terdiri dari sejumlah soal secara lisan dan/ atau tertulis, dan peserta tes diminta untuk menjawab soal tersebut secara lisan dan/ atau tertulis pula. Sedangkan alat evaluasi bentuk non-tes terdiri dari skala sikap, questioner, wawancara, pengamatan, dan lain sebagainya. Dalam kaitannya dengan tes bahasa Arab, agar tes tersebut memiliki kualitas yang baik, maka harus terpenuhi tiga kriteria, yaitu validitas, reliabilitas, dan kepraktisan. Dengan demikian, ketika guru ingin menyusun alat evaluasi bahasa Arab berupa tes, ia harus memperhatikan tiga kriteria tesebut. Selain itu, ia juga harus mempertimbangkan prinsipprinsip penyusunan tes bahasa Arab. Tanpa memperhatikan kriteria dan prinsip-prinsip penyusunan tes tersebut, dapat dipastikan hasil yang diperoleh dari tes bahasa Arab memiliki tingkat validitas dan reliabilitas yang rendah. Oleh karena itu, pengetahuan dan pemahaman tentang kriteria dan prinsip-prinsip penyusunan tes bahasa Arab harus dimiliki oleh setiap guru khsusunya guru bahasa Arab. ${ }^{3}$

Dalam pembelajaran bahasa Arab, sistem evaluasi sedikit berbeda dengan sistem evaluasi pembelajaran pada bidang-bidang pembelajaran lainnya. Adapun perbedaan tersebut terlihat pada sasaran kemampuan (al Mahārah) kebahasaan yang harus di evaluasi, maupun pada unsur-unsur (al 'Anashir) kebahasaan. Seperti telah dimaklumi, bahwa dalam pembelajaran bahasa Arab setidaknya ada empat keterampilan (al Mahārah Lughawiyyah) yang harus dikuasai peserta didik untuk memperoleh predikat bahwa ia adalah orang yang memiliki keterampilan dalam bidang bahasa Arab. Al Mahārah tersebut adalah al Mahārah Istima' (kemampuan menyimak), al Mahā rah al-Kalām (Kemampuan berbicara), al Maharah al Kitābah (kemampuan menulis), dan al Mahahārah al-Qirā 'ah (kemampuan membaca). Di samping ke empat kemampuan tersebut, seringkali dimasukkan juga beberapa kemampuan lain atau unsur-unsur terkait kebahasaan, yaitu unsur gramatikal (nahwu-sharaf), kemampuan menterjemahkan, serta kemampuan memahami wacana kebahasaan. ${ }^{4}$ Itulah kemampuan-kemampuan yang harus dimiliki oleh peserta didik dari hasil proses pembelajaran bahasa Arab.

Salah satu alat/ instrument untuk mengukur sejuahmana keberhasilan dan ketercapaian dari proses pembelajaran bahasa Arab yang bisa dilakukan oleh guru yaitu dengan penilian model tes uraian (al Ikhtibār al Maqū $\bar{l}$ ). Tes uraian (al Ikhtibār al Maqā

1 Muhbib Abdul Wahab, Perkembangan Tes Bahasa Arab Standar di Indonesia, (online) http://repository.uinjkt.ac.id/dspace/bitstream/123456789/33917/1/Muhbib_1.pdf, hlm. 869 diakses 5 Desember 2019

${ }^{2}$ Roviin, Evaluasi Pembelajaran Bahasa Arab (Kajian Tentang Instrumen Tes), Arabia, Jurnal Pendidikan Bahasa Arab, Vol 10, No 1 (2018), hlm. 196

${ }^{3}$ Roviin, Evaluasi Pembelajaran Bahasa Arab (Kajian Tentang Instrumen Tes), arabia, Jurnal Pendidikan Bahasa Arab, Vol 10, No 1 (2018), hlm. 196-197

${ }^{4}$ Maimun, Evaluasi Dalam Pembelajaran Bahasa Arab Di Stain Pamekasan, Nuansa, Vol. 8 No. 2 Juli Desember 2011, hlm. 286-287 
ini bisa dikatakan sebagai alat tes untuk mengukur kemampuan menulis (al Kitābah) atau untuk mengasah kemampuan berfikir logis para peserta didik.

\section{HASIL DAN PEMBAHASAN}

\section{Konsep Tes Uraian (مفهوم الاختبار المقالي)}

Sebelum membahasa kepada definisi tes uraian (al Ikhtibār al Maqā sangat perlu diulas kembali terkait definisi tes terlebih dahulu. Istilah tes diambil dari kata testum (Prancis) yang diartikan sebagai piring untuk menyisihkan logam-logam mulia. Ada pula yang menyebutkan sebagai sebuah piring yang terbuat dari tanah. Sementara itu istilah tes pertama kali diperkenalakan oleh seorang ahli bernama James Ms. Cattel pada tahun 1890 kepada khalayak umum melalui bukunya yang berjudul "Mental Test and Measurement". Kemudian berkembang di Amerika yang selanjutnya secara berkesinambungan berkembang dengan tempo yang pesat sampai saat ini. ${ }^{5}$

Ada beberapa istilah yang berkaitan dengan tes yaitu test, testing, tester, dan testee. Pertama, Test adalah alat atau prosedur yang digunakan untuk mengetahui atau mengukur sesuatu dalam suasana, dengan cara dan aturanaturan yang sudah ditentukan. ${ }^{6}$ Kedua, Testing merupakan waktu pada saat tes dilaksanakan. Ketiga, Tester yaitu orang yang melaksanakan pengambilan tes atau pembuat tes atau eksperimentor. Keempat, Testee yaitu responden yang mengerjakan tes. Testee tersebut yang dinilai atau diukur baik mengenai kemampuan, minat, bakat, pencapaian prestasi belajar dan sebagainya. ${ }^{7}$ Sudah tentu keempat komponen tersebut harus sudah siap semuanya demi kelancaran proses evaluasi pembelajaran tersebut

Tes merupakan salah satu upaya pengukuran terencana yang digunakan oleh guru (pendidik) untuk mencoba menciptakan kesempatan bagi para siswa dalam memperlihatkan prestasi mereka yang berkaitan dengan tujuan yang telah ditentukan. Tes terdiri atas sejumlah soal yang harus dikerjakan siswa. Setiap soal dalam tes menghadapkan siswa pada suatu tugas dan menyediakan kondisi bagi siswa untuk menanggapi tugas atau soal tersebut. ${ }^{8}$

Secara Ontologis tes bentuk uraian (al Ikhtibār al Maqāil) adalah tes yang pertanyaannya membutuhkan jawaban uraian, baik uraian secara bebas maupun uraian secara terbatas. Tes bentuk uraian ini, khususnya bentuk uraian bebas menuntut kemampuan murid untuk mengorganisasikan dan merumuskan jawaban dengan menggunakan kata-kata sendiri serta dapat mengukur kecakapan murid untuk berfikir tinggi yang biasanya dituangkan dalam bentuk pertanyaan yang menuntut ${ }^{9}$ :

a) Memecahkan masalah

b) Menganalisa masalah

c) Membandingkan

d) Menyatakan hubungan

e) Menarik kesimpulan dan sebagainya

Suharsimi Arikunto menyebutkan bahwa tes uraian (al Ikhtibār al Maqā penilaian subjektif. Tes model ini adalah sejenis tes kemajuan belajar yang memerlukkan

\footnotetext{
${ }^{5}$ I Nyoman Doni Pramana \& dkk, Evaluasi Pendidikan ..., hlm. 39-40

${ }^{6}$ Suharsimi Arikunto, 2011, Dasar-Dasar Evaluasi Pendidikan (Edisi Revisi),.... hlm. 53.

${ }^{7}$ Suharsimi Arikunto, 2011, Dasar-Dasar Evaluasi Pendidikan (Edisi Revisi),....., hlm. 68

${ }^{8}$ Ana Ratna Wulan, Pengertian Dan Esensi Konsep Evaluasi, Asesmen, Tes, Dan Pengukuran,..., hlm. 3

9 Asrur, Rusydi Ananda \& Rosnita, 2015, Evaluasi Pembelajaran, Medan: Citapustaka Media, Cet. II,
} hlm. 42-43 
jawaban yang bersifat pembahasan atau uraian kata-kata seperti; uraikan, jelaskan, mengapa, bagaimana, bandingkan, simpulkan, dan sebagainya. Sementara untuk jumlah soal bentuk uraian biasanya tidak terlalu banyak, hanya sekitar 5-10 butir soal dalam waktu kurang lebih 90 s/d 120 menit. Soal uarain (al Ikhtibār al Maqā untuk dapat mengorganisir, menginterpretasi, menghubungkan pengertian-pengertian yang telah dimiliki. Dengan singkat dapat dikatakan bahwa tes uraian (al Ikhtibār al Maqā̄i) menuntut peserta didik untuk mengingat-ingat dan mengenal kembali, terutama harus mempunyai daya kreativitas yang tinggi. ${ }^{10}$ berikut ini:

Sebagai contoh sederhana dari tes uraian (al Ikhtibār al Maqā

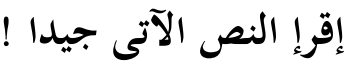

$$
\begin{aligned}
& \text { سافر إسماعيل مع والده ووالجته إلى السعودية لأداء فريضة الحج. وقضوا هناك أياما سعيدة بين مكة } \\
& \text { المكرمة والمدينة المنورة. قضوا اسبوعين في مكة زاروا فيهما بيت الله الحرام وقضو اسبوعا في المدينة زاروا فيه }
\end{aligned}
$$

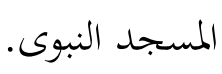

$$
\begin{aligned}
& \text { أجب الأسئلة الآتية على أساس ما فهمت من النص ! } \\
& \text { 1. ما موضوع المناسب للنص السابق ؟ } \\
& \text { كم أياما قضى إسماعيل ووالداه في مكة المكرمة المدينة المنورة؟ . }
\end{aligned}
$$

\section{Kelebihan dan kekurangan Tes Uraian (المزايا والعيوب اختبار المقالي)}

Jenis tes apapun memiliki kelebihan dan kekurangan. Bentuk tes uraian (al Ikhtibār al

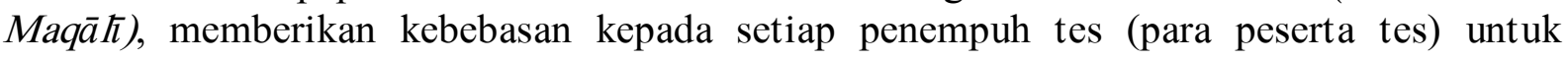
mengekspresikan daya nalarnya, sehingga jawaban yang diberikan oleh setiap penempuh tes akan menunjukkan kemampuan berpikir secara kompleks. ${ }^{11}$ Dalam pembelajaran di kelas, tes model uaraian masih banyak digunakan oleh para guru. Adapun kelebihan dan kekurangan dari tes Uraian (al Ikhtibār al Maqā Arikunto sebagai berikut ${ }^{12}$ :

a. Kelebihan Tes Uraian (المزايا من الاختبار المقالي)

Adapun kelebihan daripada tes uraian (al Ikhtibār al Maqā

a) Soal Mudah disipkan dan disusun

b) Peserta tes Tidak bisa menerka-nerka jawaban

c) Tidak memberi banyak kesempatan untuk berspekulasi atau unt ung-untungan

d) Mendorong siswa (peseta didik) untuk berani mengemukakkan pendapat serta menyusun dalam bentuk kalimat yang bagus

${ }^{10}$ Suharsimi Arikunto, 2013, Dasar-dasar Evaluasi Pendidikan Edisi 2, Jakarta: Bumi Aksara, Cet. III, hlm. 177

11 Purwo Susongko, Perbandingan Keefektifan Bentuk Tes Uraian Dan Testlet Dengan Penerapan Graded Response Model (Grm), Jurnal Penelitian dan Evaluasi Pendidikan Tahun 14, Nomor 2, 2010, hlm. 271

12 Suharsimi Arikunto, 2013, Dasar-dasar Evaluasi Pendidikan Edisi 2, Jakarta: Bumi Aksara, Cet. III, hlm. 178. Lihat juga buku Moh. Matsna \& Raswan, 2015, Evaluasi Pembelajaran Bahasa Arab, Ciputat: UIN Press, Cet. I, hlm. 22-23 
e) Memberikan kepada para peserta didik untuk mengutarakan maksudnya dengan gaya bahasa dan caranya sendiri

f) Dapat diketahui sejauh mana siswa mendalami sesuatu masalah yang di teskan.

g) Ketepatan dan kebenaran peserta tes dapat dilihat dari kalimat-kalimatnya.

b. Kekurangan Tes Uraian (العيوب من الاختبار المقالمي)

Adapun kekurangan yang terdapat dalam tes uraian (al Ikhtibār al Maqā berikut:

a) Kadar validitas dan realibilitas rendah karena sukar diketahui segi-segi mana dari pengetahuan siswa yang betul-betul telah dikuasai.

b) Kurang representative dalam hal mewakili seluruh scope (bidang) bahan pelajaran yang akan di tes karena soalnya hanya beberapa saja (terbatas)

c) Cara memeriksanya banyak dipengaruhi oleh unsur-unsur subjektif

d) Pemeriksaannya lebih sulit sebab membutuhkan pertimbangan individu lebih banyak dari penilai

e) Waktu untuk koreksinya lama dan tidak dapat diwakilkan kepada orang lain, kecuali penyusunan.

\section{Jenis-jenis Tes Uraian (أنواع الاختبار المقالي)}

Dilihat dari keluasan materi yang ditanyakan, maka tes bentuk uraian (al Ikhtibār al Maqā $\bar{l})$ ini dapat dibagi menjadi dua bentuk, yaitu: ${ }^{13}$

a) Tes uraian terbatas (اختبار المقالي المحدد), Dalam menjawab soal bentuk uraian terbatas

(Inggris: restricted respons items), peserta didik harus mengemukakan hal-hal tertentu sebagai batas-batasnya. Walaupun kalimat jawaban peserta didik itu beraneka ragam, tetap harus ada pokok-pokok penting yang terdapat dalam sistematika jawabannya sesuai dengan batas-batas yang telah ditentukan dan dikehendaki dalam soalnya.

Sebagai Contoh:

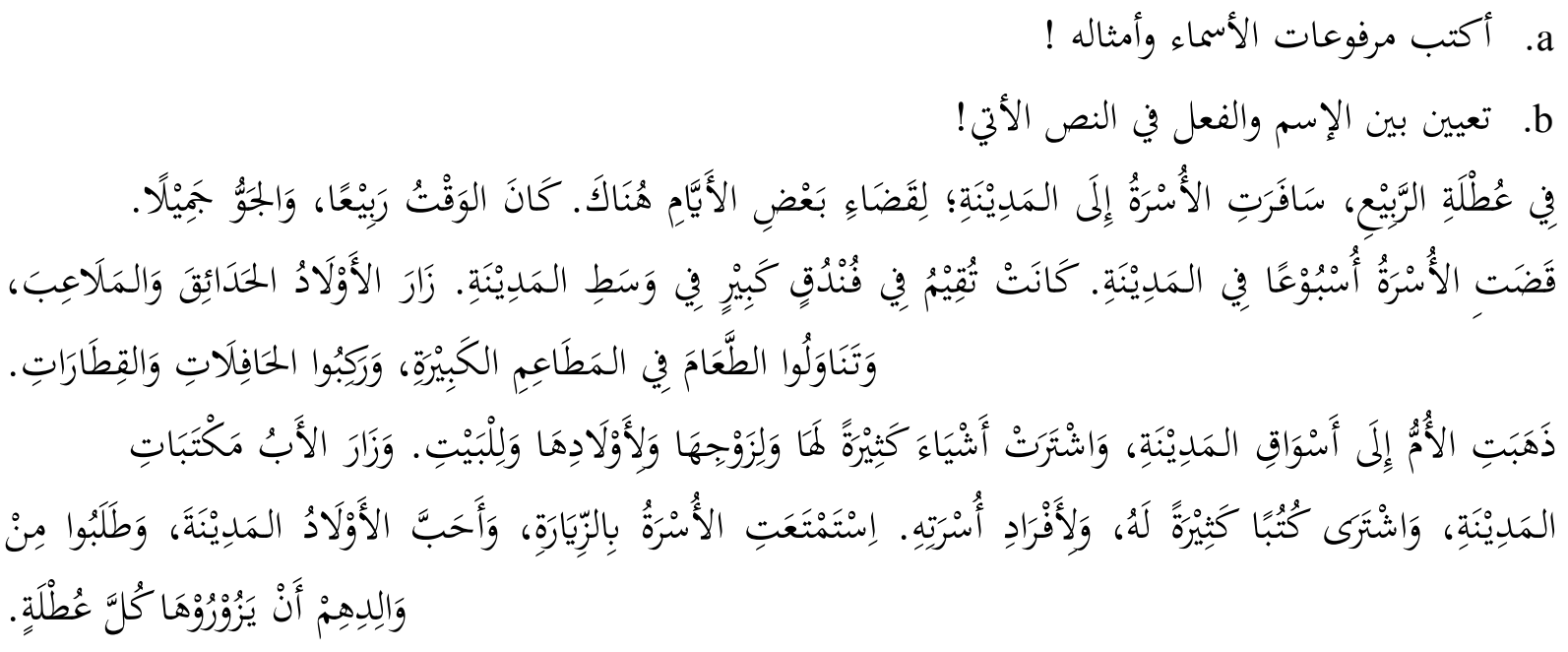

b) Tes uraian bebas (اختبار المقالي المفتوح), Dalam bentuk uraian bebas (extended respons items) ini, peserta didik bebas untuk menjawab soal dengan cara dan sistematika sendiri. Peserta didik bebas mengemukakan pendapat sesuai dengan kemampuannya. Oleh hlm. 43

13 Asrur, Rusydi Ananda \& Rosnita, 2015, Evaluasi Pembelajaran, Medan: Citapustaka Media, Cet. II, 
karena itu, setiap peserta didik mempunyai cara dan sistematika yang berbeda-beda. Namun demikian, guru tetap harus mempunyai acuan atau patokan dalam mengoreksi jawaban peserta didik nanti.

Sebagai Contoh:

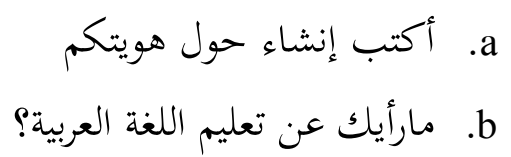

Karakteristik Tes Uraian (حصائص الاختبار المقالي)

Tes Uraian (al Ikhtibār al Maqā̄i) memliki beberapa karakteristik, yaitu ${ }^{14}$ :

a) Tes tersebut bentuk pertanyaan atau perintah yang menghendaki jawaban berupa uraian atau paparan kalimat yang pada umumnya cukup panjang.

b) Bentuk pertanyaan atau perintah itu menuntuk kepada tester untuk memberikan penjelasan, komentar, penafsiran, membandingkan, membedakan, dan sebagainya.

c) Jumlah soal butir uraiannya terbatas yaitu berkisar lima sampai dengan sepuluh butir.

d) Pada umumnya butir-butir soal uraian diawali dengan kata-kata, "uraikan",... "Mengapa",..."Terangkan",...."Jelaskan",

\section{Penggunaan Tes Uraian ( استعمال الاختبار المقالي)}

Tes uraian (al Ikhtibār al Maqā̄i) sangat baik digunakan apabila ${ }^{15}$ :

a) Jumlah peserta relatif sedikit, misalnya kurang dari 100 orang. Apabila peserta terlalu banyak, maka penggunaan tes esai akan menyita waktu guru dalam memeriksa lembar jawaban, sehingga kurang efisien waktu

b) Waktu yang dimiliki guru untuk mempersiapakan soal sangat terbatas, sedangkan ia mempunyai waktu yang cukup untuk memeriksa hasil ujian

c) Tujuan pembelajaran yang ingin di capai adalah kemampuan mengekspresikan pikiran dalam bentuk tulisan, menguji kemampuan menulis dengan baik atau kemampuan penggunaan bahasa tulis.

d) Untuk memperoleh hasil pengalaman belajar siswa, maka tes esai merupakan salah satu bentuk yang paling tepat untuk mengukur pengalaman belajar tersebut.

\section{Merancang kisi-kisi Item Tes Uraian (شعرية الاختبار المقالي)}

a. Pengertian kisi-kisi

Kisi-kisi adalah suatu format atau matriks yang memuat kriteria tentang soal-soal yang diperlukan atau yang hendak disusun. Kisi-kisi juga dapat diartikan test blue-print atau table of specification merupakan deskripsi kompetensi dan materi yang akan diujikan. Wujudnya adalah sebuah tabel yang memuat tentang perperincian materi dan tingkah laku beserta imbangan/ proporsi yang dikehendaki oleh penilai. Tiap kotak diisi dengan bilangan hlm. 43

14 Asrur, Rusydi Ananda \& Rosnita, 2015, Evaluasi Pembelajaran, Medan: Citapustaka Media, Cet. II,

15 Eko Putro Widoyoko, Evaluasi Program Pembelajaran: panduan Praktis bagi pendidik dan calon pendidik, Yogyakarta: Pustaka Pelajar, 2019, Cet. X, hlm. 87-88 
yang menunjukkan jumlah soal. Tujuan penyusunan kisi-kisi adalah untuk menentukan ruang lingkup dan sebagai petunjuk dalam menulis soal. ${ }^{16}$

b. Fungsi Kisi-kisi Adapun untuk fungsi dari dibuatnya kisi-kisi adalah sebagai berikut ${ }^{17}$ :

1) Sebagai Panduan/pedoman dalam penulisan soal yang hendak disusun Pedoman penulisan soal meurupakan aspek tepenting ketika guru hendak memberikan soal kepada siswa, pedoman tersebut akan menjadi acuan bagi guru dalam penulisan soal sehingga akan memudahkan dalam pembuatan soal.

Penulis soal akan menghasilkan soal-soal yang sesuai dengan tujuan tes. Tes merupakan bahan evaluasi guru terhadap keberhasilan peserta didik dalam pembelajaran yang disampaikan, guru dalam mengevalusi peserta didik akan memberikan soal tes evaluasi

2) yang bermacam-macam sesuai dengan tujuan pencapaian evalusi terhadap pembelajaran tertenu. Dalam pembuatan soal yang menggunakan kisi-kisi, penulis akan menghasilkan soal-soal yang sesuai dengan tujuan tes.

3) Penulis soal yang berbeda akan menghasilkan perangkat soal yang relatif sama, dari segi tingkat kedalamannyas segi cakupan materi yang ditanyakan. Penulisan kisi-kisi berfungsi untuk menselaraskan perangkat soal, sehingga hal ini juga akan mempermudah dalam proses evaluasi. berikut ${ }^{18}$ :

Pada dasarnya kisi-kisi soal yang baik harus memenuhi beberapa persyaratan sebagai

1) Kisi-kisi harus dapat mewakili isi silabus/kurikulum atau materi yang telah diajarkan secara tepat dan proporsional.

2) Komponen-komponennya diuraikan secara jelas dan mudah dipahami.

3) Materi yang hendak ditanyakan dapat dibuatkan soalnya.

\section{Kisi-kisi Soal Tes Uraian}

$$
\text { (شعرية الاختبار المقالي) }
$$

$\begin{array}{ll}\text { Satuan Pendidikan } & : \text { SMA/ MA } \\ \text { Mata Pelajaran } & : \text { Bahasa Arab } \\ \text { Kelas } & : \text { X (Sepuluh) } \\ \text { Semester } & : \text { Ganjil } \\ \text { Tahun Ajaran } & : 2019 / 2020\end{array}$

Kompetensi Inti :

KI-1 : Menghayati dan mengamalkan ajaran agama yang dianutnya

KI-2 : Menghayati dan mengamalkan perilaku jujur, disiplin, tanggung jawab, peduli (gotong royong, kerja sama, toleran, damai) santun, responsif dan pro-aktif dan

${ }^{16}$ Harlinda Syofyan, Penyuluhan Dan Pelatihan Pendidikan Tentang Pembuatan Kisi-Kisi Soal Untuk Guru-Guru Di Yayasan Perguruan Birrul Waalidain Semplak Bogor, Jurnal Abdimas Volume 3 Nomor 1, September 2016, hlm. 14

${ }^{17}$ Harlinda Syofyan, Penyuluhan Dan Pelatihan Pendidikan Tentang Pembuatan Kisi-Kisi Soal Untuk Guru-Guru Di Yayasan Perguruan Birrul Waalidain Semplak Bogor, Jurnal Abdimas Volume 3 Nomor 1, September 2016, hlm. 14

${ }^{18}$ Harlinda Syofyan, Penyuluhan Dan Pelatihan Pendidikan Tentang Pembuatan Kisi-Kisi Soal Untuk Guru-Guru Di Yayasan Perguruan Birrul Waalidain Semplak Bogor, Jurnal Abdimas Volume 3 Nomor 1, September 2016, hlm. 15 
menunjukkan sikap sebagai bagian dari solusi atas berbagai permasalahan dalam berinteraksi secara efektif dengan lingkungan sosial dan alam serta dalam menempatkan diri sebagai cerminan bangsa dalam pergaulan dunia

KI-3 : Memahami, menerapkan, menganalisis pengetahuan faktual, konseptual, prosedural berdasarkan rasa ingintahunya tentang ilmu pengetahuan, tehnologi, seni, budaya, dan humaniora dengan wawasan kemanusiaan, kebangsaan, kenegaraan, dan peradaban terkait penyebab fenomena dan kejadian

KI-4 : Mengolah, menalar, dan menyaji dalam ranah konkret dan ranah abstrak terkait dengan pengembangan dari yang dipelajarinya di sekolah secara mandiri, dan mampu menggunakan metode sesuai kaidah keilmuan.

\begin{tabular}{|c|c|c|c|c|c|c|}
\hline No & $\begin{array}{l}\text { Kompetensi } \\
\text { Dasar } \\
\text { (الكفاءة الأساسي) }\end{array}$ & $\begin{array}{l}\text { Materi Pokok } \\
\text { (الموضوع الأساسية ) }\end{array}$ & $\begin{array}{l}\text { Jumlah } \\
\text { Soal } \\
\text { Sموع السوال }\end{array}$ & $\begin{array}{c}\text { Indikator } \\
\text { (مؤشرات) }\end{array}$ & $\begin{array}{l}\text { Nomor } \\
\text { Soal } \\
\text { رقم السؤال }\end{array}$ & $\begin{array}{c}\text { Bobot } \\
\text { Soal }\end{array}$ \\
\hline 1 & 3 & 4 & 5 & 6 & 7 & 8 \\
\hline 1 & $\begin{array}{l}\text { Memahami lafal kata, } \\
\text { frase dan kalimat } \\
\text { bahasa Arab yang } \\
\text { berkaitan dengan } \\
\text { هواية الطلاب والمعرض }\end{array}$ & هواية الطاب والمعرض & 1 & $\begin{array}{l}\text { - Disajikan soal tentang } \\
\text { fi'il dan masdar. Siswa } \\
\text { mampu Menjelaskan } \\
\text { makna fi'il dan masdar } \\
\text { beserta memberikan } \\
\text { contoh dari masing- } \\
\text { masing fi'il dan masdar. }\end{array}$ & 1 & Sedang \\
\hline 2 & $\begin{array}{l}\text { Menyampaikan } \\
\text { berbagai informasi } \\
\text { lisan } \\
\text { tentang }\end{array}$ & المهنة والحياة & 1 & $\begin{array}{l}\text { - Disajikan soal dalam } \\
\text { bahasa arab dengan } \\
\text { bentuk teks pendek. } \\
\text { Siswa mampu } \\
\text { Menterjemahkan } \\
\text { kalimat bahasa Arab ke } \\
\text { dalam bahasa Indonesia } \\
\text { yang benar }\end{array}$ & 2 & Sulit \\
\hline 3 & $\begin{array}{l}\text { Memahami secara } \\
\text { sederhana dan } \\
\text { menulis, struktur teks } \\
\text { dan unsur budaya dari } \\
\text { teks terkait topik } \\
\text { lالمهنة }\end{array}$ & المهنة والحياة & 1 & 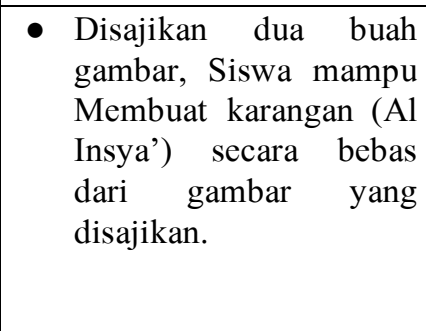 & 3 & Sulit \\
\hline 4 & $\begin{array}{l}\text { Menyampaikan } \\
\text { berbagai informasi }\end{array}$ & 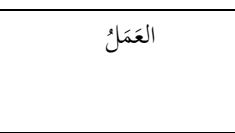 & 1 & 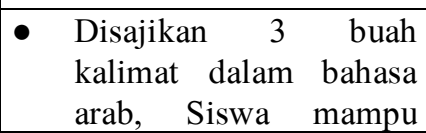 & 4 & Mudah \\
\hline
\end{tabular}




\begin{tabular}{|c|c|c|c|c|c|c|}
\hline & $\begin{array}{l}\text { lisan العَّك sederhana } \\
\text { tentangan } \\
\text { memperhatikan unsur } \\
\text { kebahasaan, struktur } \\
\text { teks dan unsur budaya } \\
\text { secara benar dan } \\
\text { sesuai konteks. }\end{array}$ & & & $\begin{array}{l}\text { Menterjemahkan } \\
\text { kalimat yang bergaris } \\
\text { bawah ke dalam bahasa } \\
\text { Indonesia yang benar. }\end{array}$ & & \\
\hline 5 & $\begin{array}{l}\text { Menyusun teks lisan } \\
\text { dan tulis sederhana } \\
\text { untuk mengungkapkan } \\
\text { informasi terkait topik } \\
\text { aلمهالمهلة } \\
\text { Dengan } \\
\text { memperhatikan unsur } \\
\text { kebahasaan, struktur } \\
\text { teks dan unsur budaya } \\
\text { secara benar dan } \\
\text { sesuai konteks. }\end{array}$ & المهنة والحياة & 1 & $\begin{array}{l}\text { - Disajikan lima kalimat } \\
\text { dalam bahasa Indonesia, } \\
\text { Siswa mampu } \\
\text { Menterjemahkan } \\
\text { kalimat berbahasa } \\
\text { Indonesia ke dalam } \\
\text { bahasa Arab yang } \\
\text { benar. }\end{array}$ & 5 & Sulit \\
\hline
\end{tabular}

\section{Contoh soal}

Soal berikut ini diambil dari buku bahasa Arab Kemenag Kurikulum 2013 kelas X, kitab al Arabiyyah Baina Yadaik, Durūsul Lughah, dan sedikit ada penambahan dari penulis.

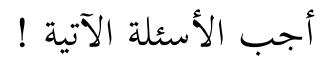

$$
\text { 1 } 1 \text { 2. بيّن الفعل والمصدر مع آت أمثاله؟ النص اللغة العربية الأتية إلى اللغة الأيدونيسية الجيدة ! }
$$

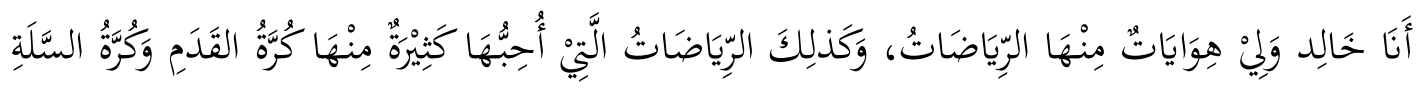

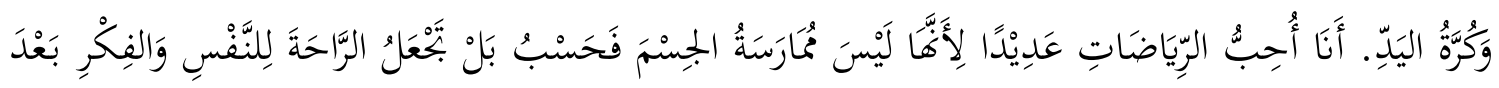

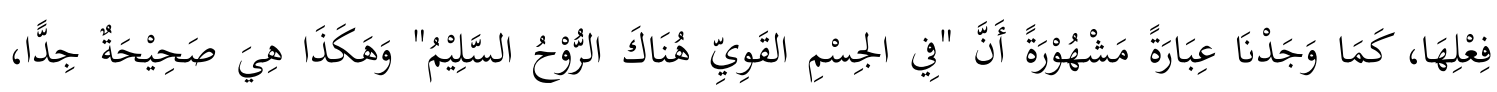

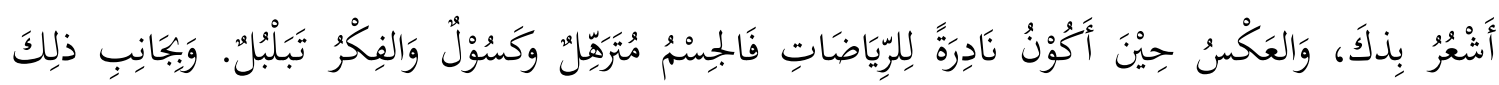

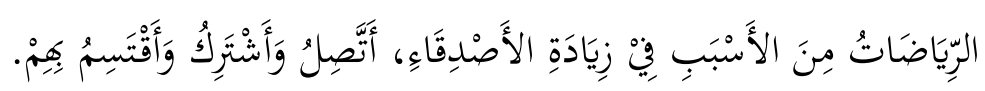

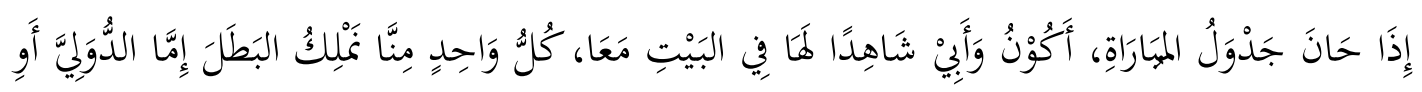

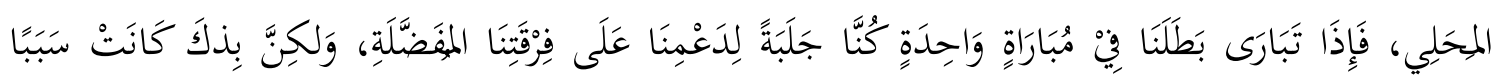

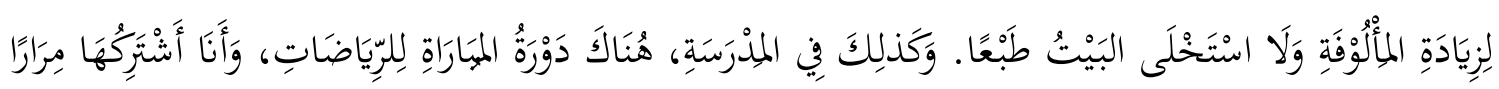




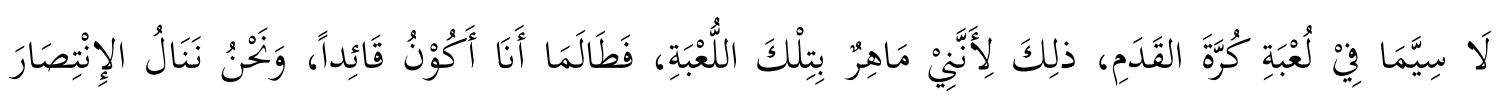
بِالكَثْيْرِ.

$$
\text { 3. 3. أكتب الفقرة عن هذه الصورتان! }
$$

صورة الثانية

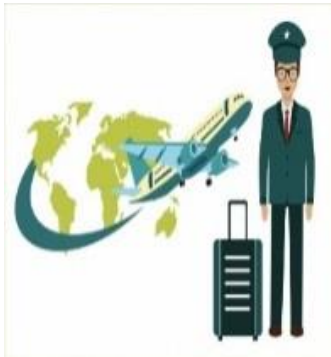

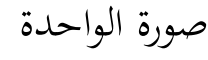

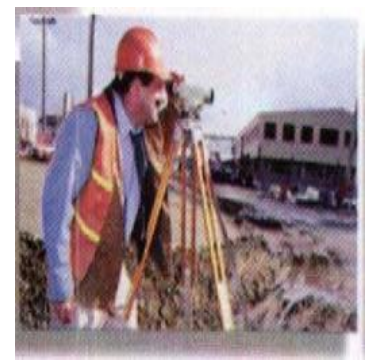

$$
\begin{aligned}
& \text { 4. ترجم الكلمة التي تحتها الخط في العبارات الأتية! } \\
& \text { 1) محمود مهندس، يعمل في شركة كبيرة. محمود يذهب إلى الشركة بالحافلة، ويعمل سبع ساعات في } \\
& \text { اليوم، ويحب عمله. } \\
& \text { 2) أحمد طبيب، يعمل في مستشفي الجامعة. يذهب أحمد إلى المستشفى بالسّيارة، ويعمل ست ساعات } \\
& \text { في اليوم ويحب عمله. } \\
& \text { 3) عمر طيار، درس الطيران في كلية الطيران، وهو يعمل في شركة الطيران. يذهب عمر مبكر إلى الشركة. }
\end{aligned}
$$

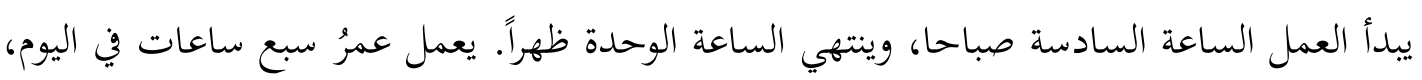

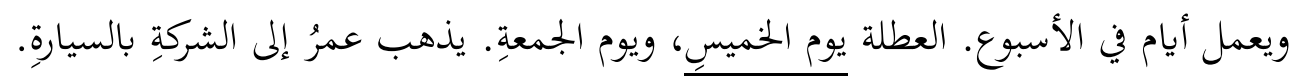

$$
\begin{aligned}
& \text { 5. 5 ترجم مايأني إلى اللغة العربية الجيدة! }
\end{aligned}
$$

a) Ibuku seorang guru, setiap hari dia berangkat ke sekolah pada jam 06.00

b) Seorang pedagang menjual pakaian di toko.

c) Pamanku adalah seorang dokter, ia pergi ke Rumah Sakit Umum

d) Wartawan ialah orang yang mencari berita dan menulisnya di koran-koran

e) Saya seorang pelajar SMA, setiap hari saya berangkat ke sekolah beserta teman-teman jam 06.15 .

\section{Teknik Penilaian Tes Uraian ( طريقة التقييم الاختبار المقالي)}

Tentunya dalam sebuah evaluasi pembelajaran harus ada sebuah pedoman atau teknik yang digunakan sebagai acuan dalam menilai hasil evaluasi peserta didik. Pedoman penilaian adalah pedoman yang digunakan untuk menentukan skor hasil penyelesaian pekerjaan siswa. Skor ini kemudian ditafsirkan menjadi nilai. Kesulitan yang dihadapi adalah menetapkan skor dengan tepat terhadap penyelesaian pekerjaan siswa, baik tugas, ulangan, atau yang 
lain. Konsistensi penskoran sangat penting untuk pemerolehan hasil penilaian antar siswa yang tidak bias dikarenakan penilaian guru yang tidak konsisten. ${ }^{19}$

Dalam jawaban tes bentuk uraian (al Ikhtibār al Maqā $\bar{l}$ ) ini tidak ada jawaban yang pasti, jawaban yang akan didapatkan dari peserta didik akan beranekaragam antara siswa satu dengan siswa lainnya. Ada sebuah saran dalam melakukan pengkoreksian terhadap hasil tes esai ini sebagaimana yang dikemukakan oleh Suharsimi Arikunto ${ }^{20}$ :

a) Membaca soal pertama dari seluruh siswa untuk mengetahui jawaban. Dengan membaca keseluruhan maka guru akan memperoleh gambaran lengkap tidaknya jawaban yang diberikan siswa secara keseluruhan.

b) Menentukkan angka untuk soal pertama tersebut. Misalkan jika jawabnnya lengkap maka diberi point (nilai) 5, kurang sedikit diberi 4, dan begitu seterusnya. Apa bila ada jawaban melesat sama sekali dalam hal ini ada dua pendapat, pertama diberikan angka 1 atau 2 bagi jawaban tersebut, ada pula pendapat lain langsung memberikan angka 0 pada jawaban yang meleset itu (tidak tepat). Tapi pada akhirnya kembali kepada guru yang bersangkutan terkait pemberian nilai tersebut.

Menghadapi situasi seperti ini kita gunakan cara pemberian angka yang relatif. Misalnya untuk suatu nomor soal jawaban yang paling lengkap hanya mengandung 3 unsur, padahal oleh si pembuat soal menghendaki lima unsur, maka pada jawaban paling lengkap itulah diberikan angka 5, sedangkan untuk yang menjawab hanya 2 atau 1 unsur dari soal tersebut kita berikan angka lebih sedikit, yaitu misalnya 3,5; 2; 1,5 dan seterusnya.

Sebagai contoh dalam kasus ini:

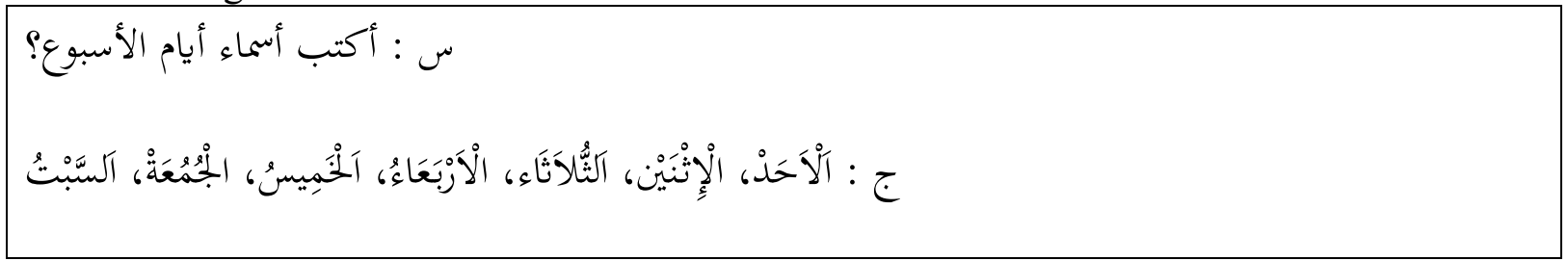

Pada kasus seperti diatas apa bila peserta didik menjawab semuanya secara utuh, maka kita bisa memberikan nilai seperti apa yang telah di jelaskan, begitupun dengan peserta didik yang menjawab sebagian maka di berikan nilai yang sesuai dengan acuan yang telah di tentukan.

c) Membaca soal kedua dari seluruh siswa untuk mengetahui situasi jawaban.

d) Menjumlahkan angka-angka yang diperoleh oleh masing-masing siswa untuk bentuk tes uraian.

Itulah beberapa saran yang dikemukkankan Suharsimi Arikunto dan bisa di aplikasikan oleh para guru disaat pelaksanaan pengkoreksian hasil evaluasi peserta didik.

\section{Rumus Perhitungan Penilaian Tes Uraian (al Ikhtibār al Maqā̄î)}

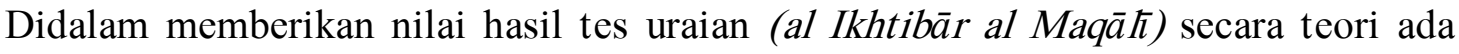
sebuah rumus yang bisa digunakan oleh guru untuk mengolah nilai hasil tes Uraian. Sebagai mana yang dijelaskan oleh Zainal Arifin dalam bukunya ${ }^{21}$, dia menyebutkan bahwa dalam tes

${ }^{19}$ Sumaryanta, Pedoman Penskoran, Indonesian Digital Journal of Mathematics and Education Volume 2 Nomor 3 Tahun 2015, hlm. 182

${ }^{20}$ Suharsimi Arikunto, 2013, Dasar-dasar Evaluasi Pendidikan (edisi kedua), Jakarta: Bumi Aksara, Cet. III, hlm. 266-267

21 Zainal Arifin, Evaluasi Pembelajaran, Direktorat Jenderal Pendidikan Islam Kementerian Agama 2012, hlm. 270-271 
uraian (al Ikhtibār al Maqū bobot. Sistem bobot ada dua cara, yaitu:

Pertama, bobot dinyatakan dalam skor maksimum sesuai dengan tingkat kesukarannya. Misalnya, untuk soal yang mudah skor maksimumnya adalah 6, untuk soal sedang skor maksimumnya adalah 7, dan untuk soal sukar skor maksimumnya adalah 10 . Cara ini tidak memungkinkan peserta didik mendapat skor maksimum sepuluh.

Kedua, bobot dinyatakan dalam bilangan-bilangan tertentu sesuai dengan tingkat kesukaran soal. Misalnya, soal yang mudah diberi bobot 3, soal sedang diberi bobot 4 , dan soal sukar diberi bobot 5. Cara ini memungkinkan peserta didik mendapat skor 10.

\section{Contoh 1: Perhitungan Skor dengan Sistem Bobot Pertama}

Pada contoh penskoran pertama ini akan coba di aplikasikkan pada kisi-kisi soal diatas. Pada kisi-kisi soal diatas terdapat 5 item soal terdiri dari mudah, sedang, dan sukar, kita gunakan penskoran dengan sistem bobot tingkat kesukaran.

Nama Siswa : Abdullah Azam

Kelas : 10 IPA

\begin{tabular}{|c|c|c|c|}
\hline No Soal & Tingkat Kesukaran & Jawaban & Skor (X) \\
\hline 1 & Sedang & Betul & 8 \\
\hline 2 & Sulit & Betul & 10 \\
\hline 3 & Sulit & Betul & 6 \\
\hline 4 & Mudah & Betul & 10 \\
\hline 5 & Sulit & Betul & 42 \\
\hline & Jumlah & & \\
\hline
\end{tabular}

Keterangan :

Rumus :Skor $=\quad \frac{\sum \mathrm{X}}{\sum \mathbf{s}}$

$\sum_{\mathrm{S}} \mathrm{X}=$ Jumlah Skor

Jadi, skor Abdullah $=\frac{44}{5}=8,8$

Akan tetapi pada dasarnya setiap sekolah mempunyai sistem penilaian tersendiri, dan penskoran diatas merupakan sebuah contoh dari teori rumus penghitungan skor mentah tes uraian (al Ikhtibār al Maqā̄î).

\section{Contoh 2 : Perhitungan Skor dengan Sistem Bobot Kedua}

Seorang peserta didik dites dengan 5 item soal dalam bentuk uraian. Masing-masing soal diberi bobot sesuai dengan tingkat kesukarannya, yaitu bobot 5 untuk soal yang sukar, 4 untuk soal sedang, dan 3 untuk soal yang mudah. Tiap-tiap soal diberikan skor (X) dengan rentang 1-10 sesuai dengan kualitas jawaban yang betul. Kemudian skor (X) yang dicapai oleh setiap peserta didik dikalikan dengan bobot setiap soal. Hasil perhitungannya adalah sebagai berikut : 


$$
\begin{array}{ll}
\text { Nama Siswa } & : \text { Abdullah Azam } \\
\text { Kelas } & : 10 \text { IPA }
\end{array}
$$

\begin{tabular}{|c|c|c|c|c|c|}
\hline No Soal & Tingkat Kesukaran & Jawaban & Skor (X) & Bobot (B) & XB \\
\hline 1 & Sedang & Betul & 10 & 4 & 40 \\
\hline 2 & Sulit & Betul & 10 & 5 & 50 \\
\hline 3 & Sulit & Betul & 10 & 5 & 50 \\
\hline 4 & Mudah & Betul & 10 & 3 & 30 \\
\hline 5 & Sulit & Betul & 10 & 5 & 50 \\
\hline & Jumlah & & & 22 & 220 \\
\hline
\end{tabular}

$$
\text { Rumus :Skor }=\frac{\sum \mathbf{X B}}{\sum \mathbf{B}}
$$

Keterangan :

TK = Tingkat Kesukaran

$\mathrm{X}=$ Skor Setiap Soal

$\mathrm{B}=$ Bobot sesuai dengan tingkat kesukaran soal

$\sum \mathrm{XB}=$ Jumlah Hasil Perkalian X dengan B

Jadi, skor Abdullah $=\underline{220}=10$

$$
22
$$

Untuk memudahkan pemberian skor, ada baiknya digunakan sistem yang kedua. Sistem bobot diberikan kepada soal bentuk uraian dengan maksud untuk memberikan skor secara adil kepada peserta didik berdasarkan kemampuannya masing-masing dalam menjawab soalsoal yang berbeda tingkat kesukarannya. Agaknya kurang adil apabila peserta didik yang sanggup menjawab soal yang sukar itu diberi skor yang sama dengan peserta didik yang hanya sanggup menjawab soal yang mudah saja. Pedoman penyekoran di atas hanya dapat digunakan untuk bentuk uraian biasa, yaitu uraian bebas dan uraian terbatas

\section{KESIMPULAN}

Dari pembahasan diatas dapat diambil kesimpulan bahwa tes uraian (al Ikhtibār al Maqā $\bar{l}$ ) merupakan salah satu alat atau instrument untuk mengukur hasil kemampuan siswa selama proses pemebalajaran. Tes uaraian (al Ikhtibār al Maqū $\tilde{\imath}$ ) masih banyak digunakan oleh para guru di sekolah dalam mengambil nilai peserta didik. Pada dasarnya tes uraian (al Ikhtibār al Maqāî) merupakan sebuah tes dengan menghendaki sebuah jawaban uraian, dan penjelasan dalam sebuah lemabaran kertas atau yang lainnya. Tes jenis ini bisa juga mengasah kemampuan peserta didik dalam hal kemahairan menulis dan daya ingat logis.

\section{DAFTAR PUSTAKA}

Arifin, Zainal, Evaluasi Pembelajaran, Direktorat Jenderal Pendidikan Islam Kementerian Agama 2012

Basir, Muhammad, 2015, Evaluasi Pendidikan, Sengkang, Lampena Intimedia, Cet. I 
Rusydi Ananda \& Tien Rafida, 2017, Pengantar Evaluasi Program Pendidikan, Medan: Perdana Publishing, Cet. I

Arikunto, Suharsimi, 2013, Dasar-dasar Evaluasi Pendidikan (Edisi 2), Jakarta: Bumi Aksara, Cet. III

Nurmawati, 2016, Evaluasi Pendidikan Islam, Bandung: Citapustaka Media, Cet. I

Asrur, Rusydi Ananda, \& Rosnita, 2015, Evaluasi Pembelajaran, Medan: Citapustaka Media, Cet. II

Purwanto, 2016, Evaluasi Hasil Belajar, Yogyakarta: Pustaka Pelajar, Cet. VII

Widoyoko, Eko Putro, 2019, Evaluasi Program Pembelajaran: panduan Praktis Bagi Pendidik dan Calon Pendidik, Yogyakarta: Pusraka Pelajara, Cet. IX

M. E. Winarno, 2014, Evaluasi Hasil Belajar Pendidikan Jasmani Olahraga Dan Kesehatan, Malang: Universitas Negeri Malang, Cet. I

Kementrian Agama RI, 2014, Buku Siswa Bahasa Arab Pendekatan Saintifik Kurikulum 2013. Direktorat Pendidikan Madrasah

Artikel \& Jurnal Online

Aziza, Ilma Fahmi, Al-Ikhtibâr Al Maqâlî Kaadawâti Al Taqwîm Litalîm Al Lughah Al Arabiyyah, Al-Wijdan: Journal Of Islamic Educations Studies, Volume 1, Nomor 1, November 2016

Siswanto, Penggunaan Tes Essay Dalam Evaluasi Pembelajaran, Jurnal Pendidikan Akuntansi Indonesia, Vol 5, No 1 (2006)

Abdul Rahman A. Gani, The Effects Of Formative Test And Learning Autonomy On The Sma Learners' Achievementin Economics, Jurnal Penelitian dan Evaluasi Pendidikan, Nomor 2, Tahun XII, 2008

Susanty, Fatimah Depi, Analisis Validasi Soal Tes Hasil Belajar Pada Pelaksanaan Pembelajaran Bahasa Arab Di Pusat Pengembangan Bahasa (P3b) Uin Suska Riau, Kutubkhanah: Jurnal Penelitian sosial keagamaan, Vol.19, No.2 Juli -Desember 2016

Murtono, \& Evi Miskiyah, Pengembangan Instrumen Evaluasi Dengan Teknik Simulasi Sebagai Asesmen Alternatif Dalam Pembelajaran Fisika Materi Mekanika Fluida Sma Kelas Xi, Jurnal Inovasi dan Pembelajaran Fisika Vol.1 No.1, Mei 2014

Nugroho, Muhammad Aji, Studi Analisis Butir Soal Latihan Buku Ajar Bahasa Arab Madrasah Tsanawiyah, Arabia, Vol, 8 No 2 Juli-Desember 2016

Mahirah B, Evaluasi Belajar Peserta Didik (Siswa), Jurnal Idaarah, VOL. I, NO. 2, Desember 2017

Sawaluddin, Konsep Evaluasi Dalam Pembelajaran Pendidikan Islam, Jurnal Al-Thariqah Vol. 3, No. 1, Januari - Juni 2018

Sari, Lia Mega, Evaluasi Dalam Pendidikan Islam, Al-Tadzkiyyah: Jurnal Pendidikan Islam, Volume 9, No. 2, 2018

Setyawan, Cahya Edi, Desain Evaluasi Program Pembelajaran Bahasa Arab (Design Program Evaluation Learning Of Arabic Language), Jurnal Komunikasi dan Pendidikan Islam, Volume 4, Nomor 1, Juni 2015 